Japanese Psychological Research

1964, Vol. 6, No. 4, 176-183

\title{
PERSONALITY CORRELATES OF PIDGIN ENGLISH USAGE AMONG JAPANESE-AMERICAN COLLEGE STUDENTS IN HAWAII
}

\author{
GERALD M. MEREDITH
}

University of Illinois

\begin{abstract}
Hawaii has developed its own characteristic speech, Island Dialect, or Pidgin English. The present study investigated the personality characteristics of college-level Japanese Americans in Hawaii referred to remedial speech courses because of severe Pidgin English usage. 79 Island-born Japanese Americans in remedial speech were compared with 60 Caucasian Americans and with 75 Island-born third-generation (sansei) Japanese-American "controls" on the Cattell 16 P. F. Questionnaire. Both first- and second-order factors in the personality sphere differentiated the groups and findings were discussed in terms of the operation of physiological, educational and socio-cultural variables.
\end{abstract}

As a result of various language influences on the speech of the islanders and the remoteness of the islands from the mainland, Hawaii has developed its own characteristic speech, Island Dialect (Pidgin English, or simply "pidgin"). In its most divergent form the island speech may have four or five vowel substitutions, consonant problems such as substituting $t$ and $d$ for the th sounds, $n$ for $n g$, and un-voicing of final consonants (Carr, 1960). Rhythm and inflection patterns also differ from standard English patterns of expression.

Historically, island dialect evolved from the "pidgin " which was used during the first half of the nineteenth century as a means of communication between traders and sailors who visited the islands and the natives (Lind, 1955). The language was carried over to the plantations when the large groups of immigrants arrived. The language in this milieu became the "language of command "used by the haole (a semi-derisive Hawaiian term meaning "foreigner," but used synonomously for a Caucasian) bosses to the laborers. At this point "pidgin" took on a lower class identification.

New ethnic groups were brought to the plantations and each added words and developed their own version of "pidgin." In time "pidgin" became the language of communication between the worker and his children born in Hawaii. When used within the group the language became one of warmth. Gradually, the language emerged into a common lingua franca which permitted easy communication across diverse racial, cultural and linguistic lines (Aspinwall, 1960).

Because the modern island dialect developed from the plantation "pidgin," it carries the stigma of its earlier lower class status. If a person is confined solely to its use he is looked down upon by polite society. Moreover, its limited vocabulary and modes of expression, as well as the virtual lack of any literature, give to his language a restricted sphere of usefulness (Lind, 1960). In spite of, or perhaps at times because, the island dialect is disapproved by the " elite," teachers, the press, and other groups, the youth of Hawaii seem to cling to their characteristic speech. Clearly, island dialect has become a mark of being " one of the gang "- a symbol of in-group acceptance by the "youth culture" (Meredith, et al., 1964).

Congruent with the recent shift in 
interest to the acculturation of thirdgeneration (sansei) Japanese Americans in Hawaii (Arkoff, 1959; Arkoff, et al. 1961; Arkoff, et al., 1962; Arkoff, et al., 1963, 1964; Fenz, et al., 1962; Meredith, et al., 1964), the purpose of the present study was to investigate the personality characteristics of college-level Japanese Americans referred to remedial speech courses because of severe Pidgin English usage.

\section{METHOD}

$S \mathrm{~s}$ consisted of 79 Island-born Japanese Americans (56 males, 23 females) enrolled in remedial speech courses at the University of Hawaii. $S$ s were referred individually by a board of speech instructors and each $S$ exhibited the typical constellation of impediments associated with Pidgin English expression, specifically, deviations in articulation, inflection and rhythrn. Comparison groups consisted of 60 Caucasian Americans (30 males, 30 females) and 75 Island-born third-generation (sansei) Japanese Americans (26 males, 49 females), all undergraduate students enrolled in the introductory psychology course at the University of Hawaii. The three groups were designated RS (Remedial Speech), CA (Caucasian Americans) and $3 G$ (Sansei Japanese Americans) for ease of discussion. Groups RS and CA were relatively free of chronic "pidgin" usage. The mean age of the RS, CA and $3 \mathrm{G}$ males were $19.2,19.2$ and 19.1 respectively. The corresponding values for the females were 18.6, 18.6 and 18.7. None of the age differences was found to be statistically significant. A basic set of source traits in the "personality sphere" based on the multivariate model of Cattell (1946) were measured with the 16 P.F. (Personality Factor) Questionnaire, Form A (Cattell, et al., 1964).

\section{Results}

1. First-order analysis

The results of the Japanese-American and Caucasian-American Groups on the 16 P.F. are summarized with respect to the above problem. Initially, means and standard deviations were computed on each scale for each of the six sub-groups (RS males, 3G males, CS males, RS females, $3 G$ females and CS females). Since the sex variable is not of major concern to the present problem, $t$ tests of significance were only computed between the personality scores within sex groups (i.e., RS vs. CS, RS vs. $3 G, 3 G$ vs. CS). Male comparisons are summarized in Table 1.

The comparison of RS and CS $S$ s indicates the ethnic disparity accentuated by the effects of language impediment on personality. In terms of primary trait description (Cattell, et al., 1964) the RS males are more reserved $(\mathrm{A}-)$, affected by feelings $(\mathrm{C}-)$, humble $(\mathrm{E}-)$, serious $(\mathbf{F}-)$, conscientious $(\mathrm{G}+)$, timid $(\mathrm{H}-)$, practical $(\mathrm{M}-)$, apprehensive $(\mathrm{O}+)$, controlled $\left(Q_{3}+\right)$ and tense $\left(Q_{4}+\right)$ than $C S$ males. Conversely, CS males are more outgoing $(\mathrm{A}+)$, emotionally stable $(\mathrm{C}+)$, assertive $(\mathbf{E}+)$, happy-go-lucky $(\mathbf{F}+)$, expedient $(\mathrm{G}-)$, venturesome $(\mathrm{H}+)$, imaginative $(\mathrm{M}+)$, placid $(\mathrm{O}-)$, casual $\left(\mathrm{Q}_{3}-\right)$ and relaxed $\left(Q_{4}-\right)$ than $R S$ males.

The comparison of RS and $3 G$ Ss indicates the relatively "pure" effect of language difficulty on personality with ethnic background held constant. In terms of primary trait description, RS males are more affected by feelings ( $\mathrm{C}-$-), humble $(\mathrm{E}-)$, serious $(\mathrm{F}-)$ and tenderminded $(\mathrm{I}+)$ than $3 \mathrm{G}$ males. Conversely, $3 \mathrm{G}$ males are more emotionally stable $(\mathrm{G}+)$, assertive $(\mathrm{E}+)$, happy-go-lucky $(\mathrm{E}+)$ and tough-minded $(\mathbf{I}-)$ than RS males.

The comparison of $3 \mathrm{G}$ and $\mathrm{CS} S \mathrm{~S}$ indicates the influence of ethnic background on personality relatively independent of language handicap. In terms of primary trait description, $3 \mathrm{G}$ males are more reserved $(\mathrm{A}-)$, humble $(\mathrm{E}-)$, conscientious $(\mathrm{G}+)$, timid $(\mathrm{H}-)$ and practical $(\mathrm{M}-)$ than $\mathrm{CS}$ males. Conversely, CS males are more outgoing $(\mathrm{A}+)$, assertive $(\mathrm{E}+)$, expedient $(\mathrm{G}-)$, venturesome $(\mathrm{H}+)$ and imaginative $(\mathrm{M}+)$ than $3 \mathrm{G}$ males.

A parallel analysis was applied to the 
TABle 1

Comparison of Males

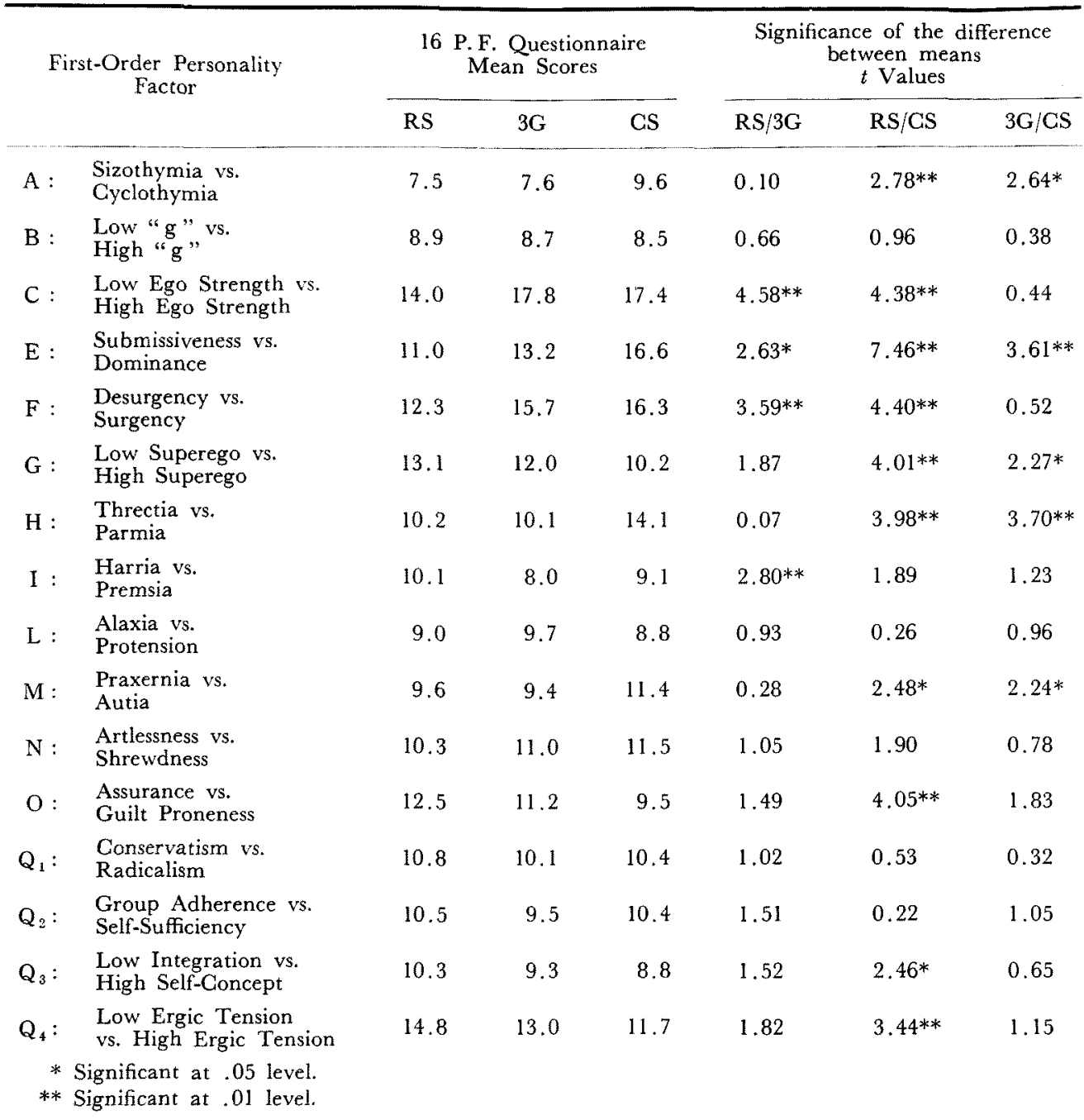

female $S_{\mathrm{s}}$ and the results are presented in Table 2. In terms of primary trait description, the RS females are more affected by feelings $(\mathrm{C}-)$, humble $(\mathrm{E}-)$, serious $(\mathrm{F}-$ ) timid $(\mathrm{H}-)$, tender-minded $(\mathrm{I}+)$, shrewd $(\mathrm{N}+)$, apprehensive $(\mathrm{O}+)$ and tense $\left(Q_{4}+\right)$ than CS females. Conversely, CS females are more emotionally stable $(\mathrm{G}+)$, assertive $(\mathrm{E}+)$, happy-go-lucky $(\mathrm{F}+)$, venturesome $(\mathbf{H}+)$, tough-minded $(\mathrm{I}-)$, forthright $(\mathrm{N}-)$, placid $(\mathrm{O}-)$, and relaxed $\left(Q_{4}-\right)$ than $\mathrm{RS}$ females.
Regarding the language handicap comparison, RS females appear more abstract-thinking $(\mathrm{B}+)$, humble $(\mathrm{E}-)$, serious $(\mathrm{F}-)$, timid $(\mathrm{H}-)$, shrewd $(\mathrm{N}+)$ and critical $\left(Q_{1}+\right)$ than $3 \mathrm{G}$ females. Conversely, $3 \mathrm{G}$ females are more concretethinking $(\mathrm{B}-)$, assertive $(\mathrm{E}+)$, happy-golucky $(\mathrm{F}+)$, venturesome $(\mathrm{H}+)$, forthright $(\mathrm{N}-)$ and conservative $\left(\mathrm{Q}_{1}-\right)$ than $\mathrm{RS}$ females.

The ethnic comparison indicated that $3 \mathrm{G}$ females are more affected by feelings 
TABLE 2

Comparison of Females

\begin{tabular}{|c|c|c|c|c|c|c|c|}
\hline \multirow{2}{*}{\multicolumn{2}{|c|}{$\begin{array}{c}\text { First-Order Personality } \\
\text { Factor }\end{array}$}} & \multicolumn{3}{|c|}{$\begin{array}{c}16 \text { P.F. Questionnaire } \\
\text { Mean Scores }\end{array}$} & \multicolumn{3}{|c|}{$\begin{array}{c}\text { Significance of the difference } \\
\text { between means } \\
t \text { Values }\end{array}$} \\
\hline & & RS & $3 G$ & CS & $\mathrm{RS} / 3 \mathrm{G}$ & $\mathrm{RS} / \mathrm{CS}$ & $3 \mathrm{G} / \mathrm{CS}$ \\
\hline \multicolumn{2}{|c|}{ A : $\begin{array}{l}\text { Sizothymia vs. } \\
\text { Cyclothymia }\end{array}$} & 10.0 & 9.1 & 10.2 & 1.11 & 0.27 & 1.64 \\
\hline B : & $\begin{array}{l}\text { Low "g" vs. } \\
\text { High "g" }\end{array}$ & 9.1 & 7.8 & 8.1 & $2.42^{*}$ & 1.60 & 0.69 \\
\hline & $\begin{array}{l}\text { Low Ego Strength vs. } \\
\text { High Ego Strength }\end{array}$ & 13.4 & 15.0 & 16.8 & 1.45 & $2.99 * *$ & $2.15^{*}$ \\
\hline & $\begin{array}{l}\text { Submissiveness vs. } \\
\text { Dominance }\end{array}$ & 9.3 & 12.0 & 13.9 & $2.83 * *$ & $4.16^{* *}$ & $2.04^{*}$ \\
\hline & $\begin{array}{l}\text { Desurgency vs. } \\
\text { Surgency }\end{array}$ & 12.3 & 15.7 & 15.4 & $3.29 * *$ & $2.78 * *$ & 0.37 \\
\hline & $\begin{array}{l}\text { Low Superego vs. } \\
\text { High Superego }\end{array}$ & 12.3 & 12.5 & 12.8 & 0.16 & 0.59 & 0.47 \\
\hline & $\begin{array}{l}\text { Threctia vs. } \\
\text { Parmia }\end{array}$ & 8.9 & 11.8 & 13.4 & $2.94 * *$ & $3.77 * *$ & 1.46 \\
\hline & $\begin{array}{l}\text { Harria vs. } \\
\text { Premsia }\end{array}$ & 13.0 & 12.0 & 11.1 & 1.53 & $2.77 * *$ & 1.65 \\
\hline & $\begin{array}{l}\text { Alaxia vs. } \\
\text { Protension }\end{array}$ & 8.7 & 9.5 & 7.7 & 1.01 & 1.27 & $2.47^{*}$ \\
\hline & $\begin{array}{l}\text { Praxernia vs. } \\
\text { Autia }\end{array}$ & 11.7 & 12.8 & 11.5 & 1.38 & 0.16 & 1.66 \\
\hline & $\begin{array}{l}\text { Artlessness vs. } \\
\text { Shrewdness }\end{array}$ & 11.2 & 8.3 & 8.5 & $4.64 * *$ & $4.11 * *$ & 0.33 \\
\hline & $\begin{array}{l}\text { Assurance vs. } \\
\text { Guilt Proneness }\end{array}$ & 13.3 & 12.4 & 9.9 & 0.97 & $3.34 * *$ & $2.68 * *$ \\
\hline$Q_{1}:$ & $\begin{array}{l}\text { Conservatism vs. } \\
\text { Radicalism }\end{array}$ & 10.6 & 9.2 & 9.5 & $2.09 *$ & 1.37 & 0.51 \\
\hline & $\begin{array}{l}\text { Group Adherence vs. } \\
\text { Self-Sufficiency }\end{array}$ & 9.7 & 9.9 & 9.4 & 0.29 & 0.27 & 0.82 \\
\hline & $\begin{array}{l}\text { Low Integration vs. } \\
\text { High Self-Concept }\end{array}$ & 9.9 & 9.3 & 9.5 & 0.58 & 0.35 & 0.28 \\
\hline \multicolumn{2}{|c|}{$\begin{aligned} & \text { Q*: } \text { Low Ergic Tension } \\
& \text { vs. High Ergic Tension } \\
& * \text { Significant at .05 level. } \\
& \text { * Significant at .01 level. }\end{aligned}$} & 16.1 & 14.7 & 13.8 & 1.43 & $2.20^{*}$ & 0.83 \\
\hline \multicolumn{4}{|c|}{$\begin{array}{l}(\mathrm{C}-) \text {, humble }(\mathrm{E}-) \text {, suspicious }(\mathrm{L}+) \text { and } \\
\text { apprehensive }(\mathrm{O}+) \text { than } \mathrm{CS} \text { females. } \\
\text { Conversely, } \mathrm{CS} \text { females are more emotion- } \\
\text { ally stable }(\mathrm{C}+) \text {, assertive }(\mathrm{E}+) \text {, trusting } \\
(\mathrm{L}-) \text { and placid }(\mathrm{O}-) \text { than } 3 \mathrm{G} \text { females. }\end{array}$} & \multirow{2}{*}{\multicolumn{4}{|c|}{$\begin{array}{l}\text { et al., 1964). Recently, Gorsuch and } \\
\text { Cattell (1964) factored the intercorrela- } \\
\text { tions between the } 16 \text { primary (oblique) } \\
\text { factors of the } 16 \text { P.F. and extracted a set } \\
\text { of second-order source traits, the most } \\
\text { salient ones being introversion-extraversion } \\
\text { (also termed invia-exvia) and anxiety. } \\
\text { Standard weights for estimating } S \text { 's endow- } \\
\text { ment on these second-order factors were } \\
\text { applied to transform } S \text { 's sten scores on the } \\
\text { primaries to sten scores on the derived } \\
\text { secondaries (Cattell, et al., 1964). }\end{array}$}} \\
\hline \multicolumn{4}{|c|}{$\begin{array}{l}\text { 2. Second-order analysis } \\
\text { A higher-order factor in the question- } \\
\text { naire (Q) domain is a source trait which } \\
\text { contributes to the variance of several pri- } \\
\text { mary source traits and is thus broader in its } \\
\text { influences (Pawlik, et al., 1964; Tsujioka, }\end{array}$} & & & & \\
\hline
\end{tabular}


TABLE 3

Second-order Personality Comparisons

\begin{tabular}{|c|c|c|c|c|c|c|c|}
\hline \multirow[t]{2}{*}{ Sex } & \multirow[t]{2}{*}{ Second-Order Factor } & \multicolumn{3}{|c|}{$\begin{array}{l}16 \text { P.F. Questionnaire } \\
\text { Mean Scores }\end{array}$} & \multicolumn{3}{|c|}{$\begin{array}{c}\text { Significance of the difference } \\
\text { between means } \\
t \text { Values }\end{array}$} \\
\hline & & RS & $3 \mathrm{G}$ & CS & $\mathrm{RS} / 3 \mathrm{G}$ & $\mathrm{RS} / \mathrm{CS}$ & $3 \mathrm{G} / \mathrm{CS}$ \\
\hline \multirow[t]{2}{*}{ Males } & Introversion vs. Extraversion & 3.7 & 4.8 & 7.5 & $2.50^{*}$ & $9.40^{* *}$ & $6.08 * *$ \\
\hline & Low Anxiety vs. High Anxiety & 7.0 & 6.3 & 5.6 & 1.49 & $3.49 * *$ & 1.45 \\
\hline \multirow[t]{2}{*}{ Females } & Introversion vs. Extraversion & 3.6 & 5.2 & 6.0 & $3.34^{* *}$ & $4.33 * *$ & 1.66 \\
\hline & Low Anxiety vs. High Anxiety & 7.1 & 6.5 & 5.4 & 1.19 & $3.21^{* *}$ & $2.32^{*}$ \\
\hline
\end{tabular}

A comparison of the RS, $3 \mathrm{G}$ and CS groups on the second-order introversionextraversion and anxiety factors is presented in Table 3. Clearly both JapaneseAmerican male groups (RS and 3G) appeared more introverted than CaucasianAmerican males. The Japanese Americans exhibit what Cattell (1957), has described as "inhibition of external reactivity (in terms of past discouragement and present timidity), and greater attention to inner stimuli and ideas (p. 268)." At this level of analysis CS males are best described as "socially outgoing, uninhibited persons, good at making contacts (Cattell, et al., 1964)." Within the Japanese-American group itself, RS males demonstrated a greater introvertive tendency than their 3G counterpart. In a parallel manner, RS females are significantly more introverted than $3 \mathrm{G}$ and $\mathrm{CS}$ females. However, $3 \mathrm{G}$ females are not as disparate from CS females as their male counterpart.

The second-order anxiety factor has been found to be the basis of clinical judgments of anxiety and, therefore, can be interpreted, in general as clinical anxiety (Gorsuch, et al., 1964). The factor score is essentially an index of the degree of dynamic integration of the total personality, under the self-sentiment $Q_{3}$, utilizing ego strength G (Cattell, et al., 1961). RS males stand out as exhibiting greater anxiety than CS males. Among the females, both Japanese-American groups (RS and
3G) indicated higher anxiety levels than CS females.

\section{Discussion}

Today many sansei Japanese-American students are bilingual, speaking nearstandard English in the classroom or to haoles, and reverting to "pidgin" with their family and peer group (Carr, 1961). The present study focused on a sub-group of Japanese-American college students referred to remedial speech classes because of their inability to effect a transition to standard English expression. If the process of acculturation is directed toward the ultimate assimilation of the ethnic individual into American society (Broom, et al., 1955), then the remedial speech $S$ s appear "farther away" from Caucasians than do the sansei "control" group. Possibly the discrepancies are most dramatically seen in terms of the second-order 16 P.F. factors. Remedial speech Ss exhibit a strong introvertive tendency coupled with an elevation of anxiety level. Some recent (but as yet unpublished) cross-cultural comparisons suggest that the first- and second-order performance of "pidgin "-speaking $S$ s is closer to the Motherland-Japanese results of Tsujioka and Cattell (1964) than to either Caucasians or sansei "controls". Admittedly the "pidgin problem" is multi-causal, and several classes of variables (e.g., physiological, educational and socio-cultural) 
have been proposed to "explain" the Island Dialect phenomenon and its relationship to personality structure.

Physiological factors include the ability to discriminate sounds and sound patterns, sensitivity to auditory stimuli, the ability to mimic, and audio-motor vs. visualmotor imagery (Kaplan, 1960; Van Riper, et al., 1958). Unpublished evidence indicates greater hearing loss among remedial speech $S$ s than Standard Englishspeaking $S \mathrm{~s}$, but the present writer concurs with Gray and Wise (1959, p. 434) that the relationships between speech mechanisms and personality are not clearly understood and that a great deal of research is needed in this general area.

Educational influences include training in phonics, ear (or listening) training, poor methods employed in speech training, and foreign language training. With regard to bilingual home background, Murashige (1950) found that the language first spoken seemed to have an effect on accuracy of auditory discrimination for English sounds. Students who spoke two or more languages before entering school made fewer errors in discriminating sounds often confused in the islands than did students who spoke only one language in the home. It is interesting that the "pidgin problem" is predominantly a male problem. Fewer females are referred to remedial speech courses and the ones that are referred have been found far superior to males in their ability to change their speech patterns. This greater flexibility, imitative skill, and readiness to change on the part of females is congruent with the findings of Penfield and Roberts (1959).

Socio-cultural influences include economic status and locality of residence of the family, peer-group expectations and personal attitudes. Merritt and Shaver (1961) have observed that students are fiercely defensive about their voices and their way of speaking. They may insist that they speak like everyone else and that any attempt to change their speech patterns will only result in artificiality and hence laughter and social disapproval. As one belligerant male in remedial speech phrased it, "Why you try change me? I no want to speak like damn haole!" There is hostility, disinterest and resistance to change among remedial speech students. A number of sociologists in Hawaii have attempted to link the "pidgin problem" with diminished classroom participation and leadership. For example, Lewis (1949) reports that students required to study remedial speech had significantly less favorable speech attitudes toward speaking in general and had done less of it in the school, home and in the community.

Two hypotheses are proposed-not to "explain" the present findings-but to suggest future lines of investigation. First, it is proposed that the elevation in anxiety level characteristic of the remedial speech sample is situationally-induced, rather than neurotic in origin (Cattell, et al., 1961). There is visible confrontation with authority and substantial pressure exerted for individuals to change. The university has stipulated that failure to remove a speech deficiency constitutes failure to meet graduation requirement-a severe consequence for speech deviancy.

Second, it is proposed that the strong introverted behavior pattern is linked to pecr-group expectations and social control. As Parsons (1964) has observed, the "youth culture" places severe demands for conformity and Hawaii has developed its own distinctive Japanese-American "youth roles." A constellation of symbols, such as clothing fads, hair styles and use of Pidgin English speech patterns form the nucleus of the "swell guy" image of the adolescent male and the "glamor girl" image of the adolescent female (Meredith, et al., 1964). It is concluded that excessive use of Pidgin English handicaps the individual socially (and possibly neurologically) from accepting the challenge for upward mobility and positions of respon- 
sibility within Japanese-American society.

\section{Summary}

The present study investigated the personality characteristics of college-level Japanese-Americans in Hawaii referred to remedial speech courses because of severe Pidgin English usage. 79 Island-born Japanese-Americans in remedial speech were compared with 60 Caucasian-Americans and 75 Island-born third-generation Japanese-Ameridan "controls" on the Cattell 16 P. F. Questionnaire. Both firstand second-order factors in the "personality sphere" differentiated the groups and findings were discussed in terms of the operation of physiological, educational and socio-cultural variables.

\section{REFERENCES}

ARkofF, A. 1959 Need patterns in two generations of Japanese Americans in Hawaii. 7. soc. Psychol., 50, 75-79.

Arkoff, A., Meredith, G., \& Dong, J. 1963 Attitudes of Japanese-American and Caucasian-American students toward marriage roles. 7. soc. Psychol., 59, 11-15.

Arkoff, A., Meredith, G., \& Iwahara, S. 1962 Dominance-deference patterning in Motherland-Japanese, Japanese-American and Caucasian-American students. F. soc. Psychol., 58, 61-66.

Arkoff, A., Meredith, G., \& Iwahara, S. 1964 Maledominant and equalitarian attitudes in Japanese, Japanese-American, and CaucasianAmerican students. 7. soc. Psychol., 64, 225229.

Arkoff, A., Meredith, G., \& Jones, R. 1961 Urban-rural differences in need patterns of third generation Japanese-Americans in Hawaii. 7. soc. Psychol, 53, 21-23.

Aspinwall, D.B. 1960 Languages in Hawaii. PMLA, 75, 7.

Broom, L., \& Kitsuse, J. I. 1955 The validation of acculturation: A condition of ethnic assimilation. Amer. Anthropol., 57, 44-48.

CARR, E.P. 1960 A recent chapter in the story of the English language in Hawaii. Social Process in Hawaii, 24, 59-60.

GarR, E.P. 1961 The fiftieth state: New dimensions for studies in speech. The Speech
Teacher, November, 288.

CAttell, R. B. 1946 The description and measurement of personality. New York: World Book Co.

Catteli, R. B. 1957 Personality and motivation structure and measurement. New York: Harcourt, Brace and World.

Cattell, R.B., \& EBer, H.W. 1964 Handbook for the sixteen personality factor questionnaire. Third edition. Champaign, III.: Institute for Personality and Ability Testing.

Catrell, R. B., \& Scheier, I. H. 1961 The meaning and measurement of neuroticism and anxiety. New York: Ronald.

Fenz, W. D., \& Arkoff, A. 1962 Comparative need patterns of five ancestry groups in Hawaii. 7. soc. Psychol., 58, 67-89.

Gorsuch, R.L., \& Cattell, R.B. 1964 (In press.) Second strata personality factors defined in the questionnaire medium by the 16 P.F.

Gray, G.W., \& Wise, C.M. 1959 The bases of speech. New York: Harper.

Kaplan, H. 1960 Anatomy and physiology of speech. New York: McGraw-Hill.

LEwIs, H. 1949 A study of the speech attitudes of the University of Hawaii freshman. Unpublished master's thesis, Univ. Hawaii.

Lind, A. W. 1955 Hawaii's People. Honolulu: Univ. Hawaii Press.

Lind, A. W. 1960 Communication: A problem of islarci youth. Social Process in Hareaii, 24, 44-45.

MEREDITH, G.M., \& Meredith, C. G. W. 1964 (In press.) Acculturation and personality among Japanese-American college students in Hawaii. 7. soc. Psychol.

Merritt, F., \& Shaver, C. L. 1961 Teaching voice and diction. In Braden, W. W. (Ed.). Speech methods and resources: A textbook for the teacher of speech. New York: Harper.

Murashige, E. T. 1950 A study of the auditory discrimination of English speech sounds in relation to languageb ackground. Unpublished master's thesis, Univ. Hawaii.

Parsons, T. 1964. Age and sex in the social structure of the United States. In Vinacke, W.E., Wilson, W. R. and Meredith, G. M. (Eds.). Dimensions of social psychology. Chicago: Scott-Foresman, Pp. 214-248.

Pawlik, K., \& Cattell, R.B. 1964 Third-order factors in objective personality tests. Brit. $\mathcal{F}$. Psychol, 55, 1-18.

Penfield, W., \& Roberts, L. 1959 Speech and 
brain-mechanisms. Princeton, N.J.: Princeton Univ. Press.

TsujiokA, B., \& Cattell, R. B. 1964 (In press.) A cross cultural comparison of second stratum questionnaire factor structures-anxiety and extraversion-in America and Japan.
7. soc. Psychol.

VAN Riper, C., \& IRwin, J. 1958 Voice and articulation. Englewood Cliffs, N. J.: Prentice-Hall.

(Received Dec., 19, 1964) 